Please do not remove this page

RMIT

UNIVERSITY

\title{
Identifying the financial barriers to deliberative, affordable apartment development in Australia
}

Sharam, Andrea; Bryant, Lyndall; Alves, Thomas

https://researchrepository.rmit.edu.au/esploro/outputs/9921862938701341/filesAndLinks?institution=61RMIT_INST\&index=null

Sharam, A., Bryant, L., \& Alves, T. (2015). Identifying the financial barriers to deliberative, affordable apartment development in Australia. International Journal of Housing Markets and Analysis, 8(4), 471-483. https://doi.org/10.1108/IJHMA-10-2014-0041

Document Version: Accepted Manuscript

Published Version: https://doi.org/10.1108/IJHMA-10-2014-0041

Repository homepage: https://researchrepository.rmit.edu.au

(c) Emerald Group Publishing Limited

Downloaded On 2023/04/26 20:15:19 +1000 


\section{DRIT \\ UNIVERSITY}

Thank you for downloading this document from the RMIT Research Repository.

The RMIT Research Repository is an open access database showcasing the research outputs of RMIT University researchers.

RMIT Research Repository: http://researchbank.rmit.edu.au/

\section{Citation:}

Sharam, A, Bryant, L and Alves, T 2015, 'Identifying the financial barriers to deliberative, affordable apartment development in Australia', International Journal of Housing Markets and Analysis, vol. 8, no. 4, pp. 471-483.

See this record in the RMIT Research Repository at:

https://researchbank.rmit.edu.au/view/rmit:47007

Version: Accepted Manuscript

Copyright Statement:

(C) Creative Commons Attribution Non-commercial International Licence 4.0 (CC BY-NC 4.0).

\section{Link to Published Version:}

https://dx.doi.org/10.1108/IJHMA-10-2014-0041 


\title{
Identifying the financial barriers to deliberative, affordable apartment development in Australia
}

\author{
Authors: Andrea Sharam ${ }^{1}$, Lyndall Bryant ${ }^{2}$, Tom Alves $^{3}$
}

\section{Abstract}

\section{Purpose}

The purpose of this paper is to identify the financial barriers to the supply of affordable apartments in Australia and examine whether demand aggregation and 'deliberative development' (self-build) can form a new affordable housing 'structure of provision'.

\section{Design/methodology/approach}

Market design, an offshoot of game theory, is used to analyse the existing apartment development model, with 'deliberative development' proposed as an innovative alternative. Semi-structured interviews with residential development financiers are used to evaluate whether deliberative development could obtain the requisite development finance.

\section{Findings}

Our investigation into the financial barriers of a deliberative development model suggest that while there are hurdles, these can be addressed if key risks in the exchange process can be mitigated. Hence, affordability can be enhanced by 'deliberative development' replacing the existing speculative development model.

\section{Research implications}

Market design is a new innovative theoretical approach to understanding the supply of housing, offering practical solutions to affordable apartment supply in Australia.

\section{Originality/value}

This research identifies financial barriers to the supply of affordable apartments; introduces theoretical understandings gained from market design as an innovative solution; provides evidence that a new structure of building provision based on 'deliberative development' could become a key means of achieving more affordable and better designed apartments.

\section{Introduction}

Australia has experienced a long period of housing price inflation coupled with a chronic undersupply of new housing stock. This has resulted in a serious decline in housing affordability for low and middle-income households (NHSC, 2013). In response, urban consolidation policies have sought to shift housing supply from greenfield sites to existing urban areas, which presupposes apartments as the new dominant housing type (Goodman et al., 2010). Such urban intensification

\footnotetext{
${ }^{1}$ Institute for Social Research, Swinburne University of Technology, Hawthorne, Victoria, Australia

${ }^{2}$ Property Economics, Science and Engineering Faculty, Queensland University of Technology, Brisbane, Queensland, Australia

${ }^{3}$ Office of the Victorian Government Architect, Melbourne, Victoria, Australia

Publication Version: Submitted to International Journal of Housing Markets and Analysis, June 2015.
} 
is frequently seen as over-development (Woodcock, Dovey, Wollan and Robertson, 2011) with apartments criticised for being generic, and of poor quality and design (Newton and Glackin, 2014). Such criticisms are laid at the feet of speculative apartment builders in the US (Pieser and Hamilton, 2014) and in the UK (Adams, 2014). Challengingly, in the Australian context, there has been no improvement in affordability (Rowley and Phibbs, 2012) despite this being a desired outcome of such urban consolidation policies.

The failure of the market to deliver affordable apartments has variously been laid at the door of the planning system, at taxation policy, and at poor construction productivity, each of which is seen as adding to the rising cost of production (Burke, 2012; NHSC, 2013, Rowley and Phibbs, 2012;). Most of these commentators typically argue lowering input costs such as government taxes and levies, and labour costs would result in cheaper housing and more supply. However, as Berry (2010) notes new housing stock generally comes onto the market reflecting prevailing market prices, suggesting demand inputs such as the increased capacity of consumers to pay, have a critical role in housing price inflation (Burke, 2012).

Given the level of policy and community concern about housing affordability there is a surprising "dearth of academic analysis of the Australian residential building sector" (Dowling 2005, p. 448), and only two studies (Judd and Dean, 1983; Rowley and Phibbs, 2012) specifically examine multiunit housing. This is not to suggest that little is known about residential development, as international and Australian texts provide instruction on the tasks involved with the development process (see Cadman and Topping, 1995; Coiacetto, 2012; Peiser and Hamilton, 2012; Reed and Sims, 2015).

Ball notes that "empirical evidence related to house-building is limited" (Ball 2012, p. 29). As Coiacetto (2001) observes our lack of understanding of apartment provision is further impeded by research that treats developers and development as homogenous. Detached, terrace housing and multi-story apartments are lumped together as if there are no substantive differences. However, Ball (1986) has long argued that each built structure type has a distinct 'structure of provision':

"Creating and building built structures invokes particular sets of social agents defined by their economic relation to the physical process of provision itself. Each historically specific set of social agents can be defined as a structure of building provision. By provision is meant the production, exchange, distribution, and use of a built structure. Involved may be a landowner, a developer, a building firm, building workers, financiers, building owners, and final users. (Ball 1986, p. 455)

The structure of provision approach infers development is dynamic and involves a temporal dimension. Drane (2013, p. 2) argues "property development is not of itself "real estate" but...a particular state of transition or change in form of real estate toward a different state with an associated change in potential or real value". This extinguishment of old property rights and the creation of new ones as D'arcy and Keogh (2002) describe it is the core of exchange for new apartments.

Burke's (2012) sub-systems approach, echoing Ball's structures of provision, divides housing into four conceptual categories: production, consumption, management and exchange. Much Australian housing research focuses on factors concerning production (such as planning systems), consumption and management (particularly social housing systems), but little attention is given to exchange. Exchange involves:

“... the practices and institutions which facilitate the sale, purchase and renting of housing, with the principal actors here being finance institutions in their many forms, and real estate practitioners. Both are important as facilitative agents in making the development, sales and purchases process possible." (Burke 2012, p. 46) 
There is a very substantial gap in the housing literature in regard to exchange and our understanding of the critical role of residential development finance in housing supply has only recently begun to be filled by Bryant (2012) and Rowley et al. (2014). Our intention here is to build on work undertaken by Sharam, Bryant and Alves (forthcoming), which draws attention to how the existing exchange sub-system for apartments mitigates against housing affordability. This work, using insights from market design, a new field of economics arising out of game theory, argues that reform of the exchange sub-system can contribute to a shift in apartment provision from a speculative basis to a deliberative basis permitting apartment purchasers to achieve considerable cost savings, thus making new housing supply more affordable.

The purpose of this research is to identify the financial barriers to deliberative, affordable housing development in Australia. The core queston is: can deliberative developers in Australia access development capital? To answer this question we interviewed those responsible for lending such development capital: residential development financiers. Residential development financiers are in a privileged position of having detailed understanding of, and deep experience with, the entire development process, often across a number of regional markets.

The article proceeds as follows. Section two explains why the exchange sub-market presents a problem for affordability and how market design may provide a solution. In section three we outline examples of deliberative development. We then turn, in section four, to the methodology used for the research and in section five provide the findings from semi-structured interviews with Australian residential development financiers. Possible solutions are presented in section six, and conclusions are drawn in section seven.

\section{Exchange Risk and Aggregation}

Housing prices are driven by many factors. In a strong housing market, new housing stock comes onto the market reflecting the price of existing housing in the vicinity (Berry, 2010). If supply lags too far behind demand, scarcity will drive asset price inflation. In a weak housing market, developers moderate supply in order to minimize potential losses. Prices are also driven by the availability of investment and mortgage finance, increased consumer capacity to borrow, competition between consumers for well-located housing (Burke, 2012), and by property speculation (Woodcock et al., 2011). Supply chain costs are important, particularly at the project viability stage (Rowley et al., 2014) and hence cost projections have a vital role in whether new supply brought onto the market (Bryant and Eves, 2014).

Sharam, Bryant and Alves (forthcoming) argue that the inability of the market to supply affordable apartments relates to the incapacity of the market to efficiently match supply and demand in order to progress an orderly and de-risked development process. The orthodox residential development process uses pre-sales ('off the plan' sales) to reduce exchange risk and lock in demand so that development finance can be released, allowing construction to commence. The purpose of the presale in the exchange process is to 'guarantee' settlement at the end of the project (Bryant, 2010), but the cost of litigation means it can be difficult for developers in practice, to obtain legal remedy if buyers opt out of the pre-sale contract. A pre-sale contract therefore only marginally reduces exchange risk, and this is far from the only difficulty. Pre-sale campaigns are often both timeconsuming and expensive because the developer, in pursuing buyers, is looking for proverbial 'needles in a haystack'. Further, greater the lapse in time between project initiation and achieving the requisite number of pre-sales, the more opportunity there is for external conditions to change: interest rates and input costs may rise; other projects may threaten over-supply; credit may tighten. Such adverse changes in any number of variables can strip a project of its profitability and viability (Rowley and Phibbs, 2012). Apartment projects brought to market this way can therefore be described as speculative, in that the project is commenced with the expectation that the residual buyers will duly be found.

From an economic perspective, such search and transaction costs incurred in this speculative 
apartment development process are problematically high. 'Market Design', an offshoot of the game theory, offers a solution. Of particular interest are 'two-sided matching markets' which aggregate buyers and sellers into formal membership pools and provide a market manager to facilitate trades. Two-sided matching markets have been implemented across many market and non-market settings, ranging from electricity wholesaling, native vegetation offsets, and human kidney donation.

Applying market design theory to apartment development, aggregators would recruit potential buyers, ascertaining their housing preferences. Registering the interest of buyers pre-identifies their demand for new apartments thus reducing developer's search costs. Aggregation of the supply side would facilitate buyer's awareness of developers and their products. Thus aggregation would remove much of the cost associated with marketing to obtain pre-sales. Aggregation also facilitates market segmentation. Currently developers provide generic product because the risk and cost of finding more differentiated demand segments renders more specialised projects unviable. If buyers are aggregated and then segmented into buyer preferences, differentiated apartment products can more closely reflect the expressed preferences of the buyers and facilitate deliberative development. Thus aggregation should limit exchange risk. Theoretically aggregation, the avoidance of a pre-sales campaign, and deliberative development should reduce apartment development risk and search costs, assuming the costs of aggregation are sufficiently low (Rijavek, 2013).

An important secondary question remains as to whether developers would pass on savings gained via aggregation. While 'market design' could deliver innovation, the oligopolistic structure of the industry (Coiacetto, 2001; Ball, 2012) may still prevent an optimal outcome for consumers. Deliberative development as an alternative structure of provision would provide the much needed competition.

\section{Deliberative development}

What is 'deliberative development'? It is where a group of intending owner-occupiers become the proponent of multi-unit developments in place of the developer. These 'self-build' apartments, can deliver better quality and design of housing together with cost savings (Lloyd, Peel, and JanssenJansen, 2015). Deliberative development in Germany has demonstrated consistent savings and better housing product (Ring, 2012), although evidence from France (Debarre and Steinmetz, 2012) and the Netherlands (Lloyd, et al., 2015) is mixed.

In Germany, 'self-build' or Baugruppen have been delivering apartments at around $75 \%$ of the market cost for many years (Alves and London, 2012; Lloyd, et al., 2015; Ring 2012). Unlike speculative-based developments, these dwellings are tailored to suit the diversity of households involved and embody other collective ambitions, such as higher environmental performance. Once the development is completed, individuals have title to their own dwelling with common property is managed by the equivalent of an owners' corporation (de Maddalena and Schuster, 2005). Architects specialise in providing project management and support for collective decision-making (Liese, 2008). German governments often support such deliberative development (Lloyd, et al., 2015). In some instances this includes actively facilitating deliberative development by designating state-owned land for this purpose, or through the subdivision of appropriately sized lots in brownfield redevelopment precincts (de Maddalena and Schuster, 2005).

In Australia, there is one publicly evaluated example of deliberative development (undertaken in Fremantle, Western Australia in the 1970s), which demonstrated cost savings similar to the German cases (Dolin, London and McQuoid, 1992). Initiated by architects, the project experienced considerable difficulties in the pre-development and development phases reflecting churn of members and financing problems. Completed at the same time as a conventional speculative development next door, the property value of the deliberative development has since far 
outstripped the value of the neighbouring speculative apartments (London, 2012). As this Australian example suggests, informal aggregation has its problems and risks, including obtaining adequate financing a key barrier.

In the next sections we provide the findings of interviews with Australian residential development financiers. The financial barriers to deliberative, affordable apartment development in Australia are identified and solutions proposed.

\section{Methodology}

As stated previously, the purpose of this research is to identify financial barriers to deliberative, development in Australia. The views of ten residential development financiers were obtained through semi-structured interviews. The financiers agreed to be interviewed on the basis of anonymity. Representatives of three of the "Big 4" banks' were interviewed, two regional lenders (representing three different states, one of which was a wholly owned subsidiary of the other Big 4 bank), two member owned banks, one property advisor/broker, and an individual who had previously worked in the finance sector. Four interviewees were Melbourne based, four Brisbane, one Sydney and one Perth. Each operated nationally, and the individual financiers had been involved in small projects such as townhouses, worth a few million dollars to large $\$ 200 \mathrm{~m}$ apartment towers.

The number of interviews reflects the concentration of the industry; risk management orthodoxy; and the limited availability of senior debt providers. The number of interviews compares favorably with previous Australian research (Rowley et al., 2014). The interviews took place between October 2012 and October 2013. Seven were conducted in person and three by telephone. Interviewees were recruited via several means: professional networks, recommendations of other interviewees or third parties, and use of Linkedln to identify people identifying as residential development financiers. Interview length varied between 30 minutes and an hour.

The interviewees were asked to describe the type and size of projects associated with their lending experience; the types of finance they provide; and what their credit assessment criteria involved, including: equity required; expertise of project proponents; security requirements; pre-sales requirements; profitability targets; contingency allowances; funding of hard versus soft costs.

They were then asked if they had any familiarity with Baugruppen type projects, what they thought the critical issues would be; and what barriers may exist for deliberative development. While the term was unfamiliar to most, the concept was not, with some lenders having previously financed syndicates to undertake such deliberative developments, albeit at the luxury end of the market. They were also asked to respond to the idea of aggregating buyers for speculative development. Once the interviews were transcribed, the responses were collated according to the questions to compare answers.

It is important to note that the nature and amount of residential development finance available at any point in time reflects market conditions. Whilst external conditions on lending are highly influential and vary considerably over time and place, on the other hand assessment of development projects by major lenders appears to be standardised, with the practice of lending governed by common procedures and formal risk management. To this end the interviews revealed a not unexpected degree of consensus on the potential financial barriers associated with funding deliberative development in Australia. 


\section{Key financial barriers}

\subsection{Credibility of the project proponent}

Project proponents of all kinds must demonstrate to their financier that they have the expertise to undertake the proposed project as well as a reliable track record of completed and profitable projects. Deliberative developers, by definition, are amateurs.

I have no material issue with twenty people [developing together]....[it's] the experience they have in doing it....we'd be looking for a lead person who understands the risk....[We] need a package where there is one borrower who has the experience and knows what they're doing in terms of development. (Banker 2)

Lack of expertise or experience was not seen as insurmountable, as prior funding of syndicate projects suggests. Financiers suggested deliberative developers could purchase experience and expertise by engaging professional project managers who would then engage appropriately credentialed construction firms and relevant professionals, in much the same way speculative developers do.

Hopefully they'll pay a good project manager who has the skills, that satisfies me as a credit manager, because he's done it twenty times before. (Banker 5)

Architects and other professionals have been instrumental in bringing the appropriate project management skills and decision-making discipline to deliberative developments in Germany. In Australia these professionals work for speculative developers on a fee for service basis and could do the same for deliberative developers. Likewise, appropriately experienced and credentialed construction and/or project management firms could be engaged on a fee for service basis with appropriate contractual and performance based protections.

Where the financiers saw risk was in the potential for a lack of robust internal decision-making and/or competing instructions being issued. This was put as the need for a single 'voice'. Again, management of this issue has been a central feature of the German experience in which architectled teams have developed processes and protocols to manage group dynamics, communications, decision-making and the line of authority.

\subsection{Loan security}

Financiers typically require collateral for development loans. Such collateral is provided as a means to minimise losses to the financier if the project fails prior to completion, the loan terms are breached, or any other event occurs that might disrupt repayment of the loan with interest. Mitigating such financial risk is by way of legal instruments (eg. first registered mortgage, fixed and floating charges, negative pledges etc.) that give lenders recourse to assets including land, project documentation, and pre-sale contracts. Loans are also secured by way of tri-partite agreements with third parties such as builders, with banks given step-in rights.

The financiers interviewed reported taking additional security from developers in the form of corporate and/or personal guarantees from directors where project assets were insufficient collateral. What this means for deliberative developments is that in the event of a loan default, the project proponents may need to sell assets, to raise funds to repay the development loan.

Some of the financiers were particularly nervous about the potential for adverse publicity if there was a mortgagee repossession of a deliberative development project. In speculative development, corporate assets are repossessed and liquidated however in the deliberative development model, the bank may need to evict families in order to take possession of the family home put up as collateral. 
If something goes wrong and it all gets totally stuffed up and we lose a million dollars we don't want to be on the front page of the Herald-Sun suing couples because they're tried to do the right thing and we're the bad guys. (Banker 1)

A greater issue was that deliberative developers might not have sufficient unencumbered assets to pledge in the first instance. As with other forms of borrowing, the participation of a guarantor was seen as a possible solution.

If as a banker I know I have a guarantee - that someone's on the hook - then that's great. If you give Rupert Murdoch ii as a guarantor —no worries! (Banker 5)

\subsection{Equity}

Financiers generally fund only a proportion of the development costs, with the remainder of the monies provided by the project proponents. The amount the financier is willing to fund depends on the financier's risk assessment of the project.

The financiers interviewed indicated deliberative developers would be treated the same as speculative developers, requiring equity contribution of between 25 and $40 \%$ of total development costs. Further, the proponents would need to demonstrate additional financial capacity to fund cost over-runs. This parameter suggests that deliberative development would need to overcome a significant 'equity gap'. By way of example, if we assume the cost to develop per apartment (including land) is $\$ 400,000$, an equity contribution of $25 \%$ would equate to $\$ 100,000$ per apartment. A $\$ 100,000$ cash equity contribution is a considerable hurdle for moderate-income households. We will return to this point in section six.

\subsection{Pre-sales}

Financiers require speculative developers to achieve high pre-sales quotas prior to the release of funding as a method of securing repayment of the loan. Financiers suggested this sales and marketing expense constitutes as much as $10 \%$ of total project costs, 'making it more costly than the finance' (Banker 1). While deliberative development avoids the need for a pre-sales campaign through prior aggregation of 'buyers', the financiers said they would treat the project proponents (as intending owners) as if they were pre-sales. The reduced project costs were viewed as reducing project risk.

Asked to reflect on whether aggregation could have a similarly positive financial impact on a speculative development venture, most of the financiers agreed and some cited examples of large developers moving away from traditional pre-sales campaigns because of the high cost. The others did not disagree but rather needed time to work through the implications of the aggregation concept. Tellingly, Banker 2 argued speculative developers would simply expropriate the savings rather than pass them through to the buyers. While the costs of establishing and operating aggregators is unknown, these remarks confirm aggregation should be regarded as a promising market innovation that holds the possibility of reducing the cost of housing provision.

It is worth noting here that deposits paid on pre-sales however are not available to fund the project. They are held in trust under Australian Consumer Law.

\subsection{Profitability}

The raison d'être of deliberative development is threefold: to avoid the cost of a presale campaign, to aggregate owner-occupiers with similar housing requirements; and to save the cost of providing a profit margin to a speculative developer. The financiers indicated however deliberative development would still need to demonstrate the project could achieve a profit margin of at least $20 \%$ if the apartments were sold on the open market. This is the minimum a financier would expect from a speculative developer.

From a planning and project perspective I still want to see some profit, a margin. (Banker 5) 
As discussed in the section on LVR (below), the sale price is hypothecated by virtue of a market valuation; an actual sale does not need to occur. In effect, the financiers are simply requiring the apartments to be worth more on the market than they cost by a margin of $20 \%$. In economic terms this 'profit' would be internalised by the project proponent as residual equity. As with LVR it means the apartments would need to have broad appeal.

\subsection{Loan to Value (LVR) ratio}

Loan amounts are determined in relation to the end value of the project (known as the loan to value ratio). This metric is a reflection of the lender's worst case scenario of what funds would be recouped in a mortgagee in possession situation. An LVR of $65 \%$ was suggested by most of the financiers as appropriate for deliberative development. Again assuming a total cost per apartment of $\$ 400,000$ and a hypothecated profit margin of $20 \%$, a market valuation upon completion would need to be at least $\$ 480,000(\$ 400,000 * 120 \%)$. An LVR of $65 \%$ therefore suggests the financier would lend $\$ 312,000\left(\$ 480,000^{*} 0.65\right)$ of the forecast $\$ 400,000$ construction cost per apartment. Thus requiring an equity contribution of $\$ 88,000$ per apartment.

Financiers require confirmation by way of independent valuation that the end product would find market acceptance thus enabling the lender to recoup their funds should the loan default. Market acceptance involves a number of elements. The product itself would need to attract buyers; so individual apartments would need to have broad appeal, as would the overall development and location.

We need to make sure we get our money back.... [They need to] deliver a product the market will look at. (Banker 3)

This presents a serious problem for deliberative development that seeks to reduce housing cost via accessing cheaper land in less desirable locations. The proponents may not be able to establish that there would be alternative buyers for the proposed product at a price that is competitive with pre-existing stock in that area. It would also potentially preclude overly innovative or specialised apartment designs.

\subsection{Conclusions}

A number of the financiers interviewed had previously financed small syndicates engaged in deliberative development, although these were high net worth individuals with 'deep pockets' who could 'afford to fail' and who had other assets to provide for collateral and/or required equity. These projects however had been driven by the desire to obtain a specific architectural product, in specific locations rather than to address affordability concerns.

The larger lenders were concerned about impacts of deliberative developments, undertaken by lower income households, failing. Some bankers were nevertheless concerned about the need to find a means of delivering more affordable housing.

The member-owned banks applied the same metrics as the public companies but indicated a greater willingness to consider deliberative development, as the cooperative nature of such projects reflects their own missions or ethos.

The financiers agreed deliberative developers could acquire development credibility by hiring industry professionals to manage their projects. The rather pessimistic assessment of equity requirements, loan security provisions and the possible constraints of LVR requirements, was tempered by the financiers accepting deliberative development could reduce demand risk and generate cost savings. More optimistically, the financiers indicated there were possible solutions to the equity and loan security issues that would permit less wealthy households access to deliberative development. 


\section{Possible solutions}

Potential solutions to the financial barriers identified for deliberative development were discussed with the financiers. The greatest potential barrier was the equity/security requirements of the bank versus the available funds of affordable households. The financiers suggested the introduction of a guarantor, such as government, which would result in a more favourable LVR and thus lower the equity requirement threshold. An alternative to a government guarantee would be access to other asset rich balance sheets. Community housing organisations $(\mathrm{CHOs})$ were identified as a possible provider.

\section{community housing organisation $[\mathrm{x}]$ are in effect already doing this (Banker 4)}

CHOs in Victoria for example, build and manage social housing for low to moderate-income households. At June 2013 the Victorian CHO sector held $\$ 2.5$ billion worth of assets with interest bearing debt of only $\$ 309 \mathrm{~m}$ (DTF, 2014). Gearing is modest as revenue is limited by the requirement to provide affordable rent. In short, the sector is asset rich but income poor. Therefore the balance sheet of a $\mathrm{CHO}$ could be used, effectively on a fee for service basis, as security for obtaining finance for deliberative developers, either via a financial guarantee provided to bankers or the $\mathrm{CHO}$ borrowing on the behalf of the deliberative developers. This would overcome the critical problem deliberative developers have of providing sufficient collateral. Fees generated by the $\mathrm{CHO}$ from this activity could be used to support social housing development and/or services.

The two member-owned banks interviewed (as funders of social housing) were particularly supportive of $\mathrm{CHOs}$ playing this role, and could foresee mixed tenure developments (combining deliberative development and social housing) with the deliberative development 'pre-sales' reducing the development risk. In this way, mixed social housing/deliberative development would reward private house owners willing to have social housing tenants as neighbours, with lower housing costs. This could mitigate some community opposition to social housing provision, and would achieve the social diversity desired by mixing tenures. Government or philanthropy could establish a guarantee in the form of a revolving social investment fund to support this type of development.

Common Equity Housing Ltd, a registered housing association operating in Victoria, and the Business Council for Cooperatives and Mutuals (BCCM), are actively investigating how to foster cooperatively-based deliberative developments for households ineligible for social housing but struggling in the market (BCCM and CEHL, 2014). Central to this innovative concept is the capacity of CEHL, by virtue of its healthy balance sheet, to secure development finance.

\section{Conclusion}

This research has identified the financial barriers to the supply of affordable apartments in Australia and examined whether demand aggregation and deliberative development can provide a new affordable housing "structure of provision".

Following the insights of market design, the economic inefficiency of the traditional presales process can be overcome by aggregating buyers, which would also provide the opportunity to deliver more tailored housing products. The quest for affordable, quality apartments requires economic actors who are willing and able to commit to the supply of such housing and the most obvious candidates are consumers themselves. This theory has informed international deliberative development groups which have established a credible track record of reducing the cost of new apartments. Such deliberative development has been limited in Australia to date reflecting the considerable financial barriers. However these barriers could be addressed if support was provided, with the community housing sector being one logical collaborator.

The contribution of this research is three-fold. Firstly, it introduces innovation in terms of how we 
think about attracting and managing demand for housing by making explicit linkages between market design theory and the traditional structure of provision for apartments in Australia. In doing so, it articulates a new structure of provision, moving from speculative to deliberative development. Secondly, this research moves beyond theoretical concepts, to initial market testing of this innovation. Having identified the ability to raise capital as a key barrier, this research provides an important insight into the opaque spectrum of development finance. Through this applied inquiry, it has been established that while hurdles exist, potential solutions exist that can facilitate the success of this innovative idea. Finally, this research adds to the scant international literature on the topics of both deliberative development and of development finance. Therefore, this research provides a contribution to the affordable housing debate and is a step towards delivering much needed reform to housing provision in Australia.

Further research on this topic will seek to identify and examine other case studies of deliberative development in Australia. The key learnings of such case studies will be documented with a view to developing a best practice model.

\section{References}

Adams, D. (2014), "United Kingdom: growth, structure and priorities of the UK real estate development industry: the longstanding division between commercial and residential developers", in Squires, G. and Heurkens, E. (Ed.), International Approaches to Real Estate Development, Taylor and Francis, Hoboken, pp. 46-65.

Alves, T. and London, G. (2012), "New Housing for a Shifting Urban Paradigm: Housing Development Co-operatives as a More Affordable and Sustainable Alternative for Housing Provision in Australian Cities", paper presented at the 6th Australasian Housing Researchers Conference Proceedings, 8-10 February, Adelaide, Australia.

Ball, M. (1986), "The built environment and the urban question", Environment and Planning D: Society \& Space, Vol. 4 No. 4, pp. 447-464.

Ball, M. (2012), "Housebuilding and housing supply", Clapham, in D., Clarke, A., and Gibb, K. (Ed.), The SAGE Handbook of Housing Studies, Sage Publications, Thousand Oaks, USA, pp. 27-47.

Berry, M. (2010), "Housing Wealth and Mortgage Debt in Australia", in Smith, S. and Searle, B. (Ed.) The Blackwell Companion to the Economics of Housing, Wiley-Blackwell, UK, pp. 126146.

BCCM (Business Council of Cooperatives and Mutuals) and CEHL (Common Equity Housing Ltd) (2014), Breaking Through the Affordability Ceiling, National Housing Round Table, $25^{\text {th }}$ February 2014, Melbourne.

Bryant, L. (2010), "The Impact of the Global Financial Crisis on Real Estate Development and Project Finance in Queensland", in Proceedings of 2010 International Conference on Construction Real Estate Management, China Architecture \& Building Press, Brisbane, Australia, pp. 386-391.

Bryant, L. (2012), "An Assessment of Development Funding for New Housing post-GFC in Queensland, Australia”, International Journal of Housing Markets and Analysis, Vol. 5 No. 2, pp. 118-133.

Bryant, L. and Eves C. (2014), "The link between infrastructure charges and housing affordability in Australia: where is the empirical evidence?", Australian Planner, Vol. 51 No. 4, pp. 307-317.

Burke, T. (2012), "The Australian residential market: institutions and actors", in Tomlinson, R. (Ed.), Australia's Unintended Cities: The Impact of Housing on Urban Development, CSIRO Publishing, Collingwood, pp. 35-50. 
Cadman, D. and Topping, R. (1995), Property Development, 4th ed. Spon Press, London, UK.

Coiacetto, E. (2001), "Diversity in real estate developer behaviour: A case for research", Urban Policy \& Research, Vol. 19 No. 1, pp. 43-59.

Coiacetto, E. (2012), Understanding Land Development: A Project-Based Approach, CSIRO Publishing, Melbourne, Australia.

D'arcy, E. and Keogh, G. (2002), "The market context of property development activity", in Guy, S. and Henneberry, J. (Ed.), Development and developers: perspectives on property, Blackwell Science Ltd, Oxford, UK, pp. 19-34.

Debarre, A. and Steinmetz, H. \& translated by Waine, O. (2012), "(Re-)Inventing self-build housing in Strasbourg", Metropolitics, URL : http://www.metropolitiques.eu/Re-Inventing-self-buildhousing-in.html (accessed 17 October, 2014)

de Maddalena, G. and Schuster, M. (2005), Go south: the Tübingen model, trans. Geoffrey Steinherz, Ernst Wasmuth, Tübingen.

Dolin, A. London, G. and McQuoid, K. (1992), Sector 4 Housing: a Concept to Address the Need for Urban Consolidation and Better Communities - A Report to The Office of The Family, Government of Western Australia, The Rowland Company, West Perth.

Dowling, R. (2005), "Residential Building in Australia, 1993-2003", Urban Policy \& Research, Vol. 23 No. 4, pp. 447-464.

Drane, J. (2013), "The state of contemporary property development theory", paper presented at 19th Annual Pacific Rim Real Estate Society Conference (PRRES), 13-16 January, Melbourne, Australia, available at:

http://www.prres.net/papers/Drane The State Of Contemporary Property Development Theo ry.pdf (accessed 20 November, 2013).

DTF (Victorian Department of Treasury and Finance) (2014), Sector performance 2012-13 Victorian registered housing agencies, Victorian Department of Treasury and Finance, Melbourne.

Goodman, R. Buxton, M. Chhetri, P. Taylor, E. and Wood, G. (2010), Planning and the Characteristics of Housing Supply in Melbourne, AHURI Final Report No. 157, Australian Housing and Urban Research Institute (AHURI), Melbourne.

Judd, B. and Dean, D. (Eds.) (1983), Medium Density Housing in Australia, RAIA Education Division, Canberra.

Liese, J. (2008), "House-building cooperatives - a model for the future", Detail: Review of Architecture, Vol. 48 No. 9, pp. 902-906.

Lloyd, M. Peel, D. Janssen-Jansen, L. (2015), "Self-build in the UK and Netherlands: mainstreaming self-development to address housing shortages?", Urban, Planning and Transport Research, Vol. 3 No. 1, pp. 19-31.

London, G. (2012), Comment by the Victorian Government Architect, Housing Development Cooperatives workshop, Office of the Victorian Government Architect. 22 August 2012, East Melbourne.

Newton, P. and Glackin, S. (2014), "Understanding infill: towards a new policy and practice for urban regeneration in the established suburbs of Australia's cities", Urban Policy \& Research, Vol. 32 No. 2, pp. 121-143.

NHSC (National Housing Supply Council) (2013), Housing Supply and Affordability Issues 201213, Commonwealth of Australia, Canberra.

Peiser, R. and Hamilton, D. (2012), Professional Real Estate Development The ULI Guide to the Business, 3rd ed., Urban Land Institute, Chicago.

Reed, R. and Sims, S. (2015), Property Development, Sixth Edition, Routledge, Melbourne. 
Rijavec, I. (2013), Why Citiniche?, http://citiniche.com.au/blog/why-citiniche/ (accessed February $6^{\text {th }}$ 2013).

Ring, K. (2012). Self Made City, Jovis, Berlin.

Rowley, S. and Phibbs, P. (2012), Delivering diverse and affordable housing on infill development sites, AHURI Final Report No.193, Australian Housing and Urban Research Institute (AHURI), Melbourne.

Rowley, S., Costello, G., Higgins, D. and Phibbs, P. (2014), The financing of residential development in Australia, AHURI Final Report No. 219, Australian Housing and Urban Research Institute (AHURI), Melbourne.

Sharam, A., Bryant, I. and Alves, T. (forthcoming), "De-risking development of medium density housing to improve housing affordability and boost supply", Australian Planner.

Woodcock, I., Dovey, K., Wollan, S., and Robertson, I. (2011), "Speculation and Resistance: Constraints on Compact City Policy Implementation in Melbourne", Urban Policy \& Research, Vol. 29 No. 4, pp. 343-363.

\footnotetext{
'The 'Big 4' banks dominate Australia's notoriously concentrated banking system. The number of lenders reduced further in the aftermath of the GFC with less than $20 \%$ of residential development lenders remaining (Kent, 2009), with a number of regional lenders merging with the Big 4 banks but continuing to trade as separate entities. The Big 4 banks continue to undertake the majority of lending in residential development (Bryant, 2012).

ii Rupert Murdoch is an Australian born American businessman and according to the Forbes' 2013 list of richest Americans is the 33rd richest person in the US and the 91st richest person in the world.
} 